\title{
Lack of Control of Citrus Canker by Induced Systemic Resistance Compounds
}

\author{
J. H. Graham, Professor, University of Florida, IFAS, Soil and Water Science Department, Citrus Research and \\ Education Center, Lake Alfred 33850, and R. P. Leite, Jr., Plant Pathologist, Instituto Agronômico do Paraná, Lon- \\ drina, Paraná, Brazil
}

\begin{abstract}
Graham, J. H., and Leite, R. P., Jr. 2004. Lack of control of citrus canker by induced systemic resistance compounds. Plant Dis. 88:745-750.

Induced systemic resistance compounds (ISRs), acibenzolar- $S$-methyl (Actigard), and harpin protein (Messenger) were assayed in the greenhouse against Xanthomonas axonopodis pv. citrumelo, the cause of citrus bacterial spot (CBS), and X. axonopodis pv. citri, the cause of Asiatic citrus canker. Actigard and Messenger applied as foliar sprays 3 to 7 days before inoculation reduced numbers of lesions when either bacterium at $10^{3}$ or $10^{4} \mathrm{CFU} / \mathrm{ml}$ was injectioninfiltrated into Swingle citrumelo leaves. Based on this activity, the ISRs were evaluated in southern Brazil in orchards of sweet oranges with low to moderate canker disease incidence in spray programs with and without copper oxychloride (COC) and copper hydroxide $(\mathrm{CuOH})$. Actigard and Messenger were applied full season or in the first two or three sprays of a six-spray program in an attempt to reduce early canker disease on foliage and thereby reduce subsequent fruit infection and premature drop. Sprays of $\mathrm{COC}$ and $\mathrm{CuOH}$ were moderately to highly effective in reducing canker disease incidence and preventing premature fruit drop. Actigard or Messenger in combination with $\mathrm{COC}$ and $\mathrm{CuOH}$, respectively, did not significantly reduce citrus canker incidence on foliage or fruit drop compared with $\mathrm{Cu}$ alone. The lack of additional control with ISRs means they cannot be recommended at this time to augment $\mathrm{Cu}$ programs for management of citrus canker.
\end{abstract}

Outbreaks of the leaf and fruit spotting disease Asiatic citrus canker, caused by Xanthomonas axonopodis pv. citri, continue to occur in metropolitan areas of Tampa, Miami, Orlando, and southwest Florida (6). Minor outbreaks scattered throughout commercial citrus in southern Florida persist despite aggressive effort by a citrus canker eradication program (25). The existence of a large reservoir of infected and exposed citrus in metropolitan Miami and the frequency of outbreaks in commercial citrus jeopardize the prospects for effective eradication $(6,25)$. The situation raises concern within the citrus industry regarding management of citrus canker should the disease become permanently established in Florida.

Induced systemic resistance (ISR) is the process of resistance dependent on the host

Corresponding author: J. H. Graham

E-mail: jhg@crec.ifas.ufl.edu

This research was supported by the Florida Agricultural Experiment Station and a grant from the Florida Citrus Production Research Advisory Council (Project 013-07P) to JHG and by a grant from PADCT/MCT, Brazil (no. 64.99.032.02) to RPL Jr. The authors also appreciate support from Syngenta Crop Protection and Eden Bioscience. This manuscript is approved for publication as Journal Series No. R-09476.

Accepted for publication 16 March 2004.

Publication no. D-2004-0429-01R

(C) 2004 The American Phytopathological Society plant's physical or chemical barriers, activated by biotic or abiotic inducing agents $(12,13)$. ISR is not the same as systemic acquired resistance (SAR), which is regulated through a distinct signal transduction pathway. Salicylic acid is implicated in SAR regulation, whereas jasmonic acid is implicated in ISR regulation. Different antimicrobial proteins are induced in the two pathways, but the distinction of terminology is somewhat confused by cross-talk between the two pathways. The term ISR will be used here to include ISR and SAR inducers with activity against several pathogens. Compounds such as benzothiadiazoles and harpin protein are known inducers of plant resistance to diszolar-S-methyl, a benzothiadiazole, registered as Actigard in the United States (Syngenta Crop Protection), and harpin protein, a hrp gene product registered as Messenger (Eden Bioscience), are marketed for control of certain diseases $(2,30)$. ISRs are not viewed as replacements for traditional fungicides and bactericides, but they may allow for reduction in the number and dosage of applications of contact materials $(24,30)$.

Copper $(\mathrm{Cu})$-based bactericides are a standard control measure for citrus canker worldwide $(14,16,28)$. Cu reduces bacterial populations on leaf surfaces, but multiple applications are needed to achieve adequate control on susceptible citrus hosts such as grapefruit and sweet orange $(8,17,26,27,28)$. Cu-based spray programs eases $(2,3,32)$. The compounds aciben- are targeted to the spring leaf flush to protect leaves from the one-half to full expansion stage over a period of 2 to 4 weeks $(10,28)$. Fruit are susceptible as they grow from 2.0 to $6.0 \mathrm{~cm}$ in diameter for a period of 90 to 120 days, depending on citrus species (11). Protectant activity of $\mathrm{Cu}$ is diminished by windblown rain, which introduces bacteria directly into stomata $(4,5)$. Therefore, $\mathrm{Cu}$ is used in combination with windbreaks in South America under weather conditions similar to Florida $(7,15,16,20)$. After long-term use, $\mathrm{Cu}$ bactericides have other possible disadvantages, including resistance in xanthomonad populations $(18,22)$ and accumulation in soils with potential phytotoxic and environmental effects (1). However, other contact bactericides including antibiotics are not as effective as $\mathrm{Cu}(17,19,22,31)$, and antibiotic resistance has developed within xanthomonad populations $(21,23,29)$.

Several mechanisms for ISR may operate simultaneously to control the pathogen, thus reducing the risk of development of resistance (30). ISR activity potentially could be deployed early in the season to slow growth of the bacterium in rapidly developing leaves and complement the protectant activity of $\mathrm{Cu}$. Testing of novel control measures against citrus canker in Florida is restricted to greenhouses under containment and to outdoor evaluation of limited scope in quarantine zones. To determine the value of ISRs, Actigard and Messenger were first tested in a greenhouse assay to establish efficacy against citrus bacterial spot, a surrogate xanthomonad disease caused by $X$. axonopodis pv. citrumelo (9), and then against citrus canker under containment. Based on activity in the greenhouse, orchard trials were conducted in Paraná State, Brazil, where citrus canker is endemic. In these trials, early and season-long sprays of ISRs in combination with $\mathrm{Cu}$ formulations were evaluated for control of fruit-blemishing and disease-induced fruit drop.

\section{MATERIALS AND METHODS}

Bacterial cultures. $X$. axonopodis pv. citrumelo strain F1 isolated from a citrus nursery in 1984 (9) and X. axonopodis pv. citri X02-007 isolated from residential citrus in Broward County in 2001 were maintained by serial transfer on nutrient agar (NA) and periodically reisolated from inoculations described below to maintain virulence. For greenhouse tests, bacteria were grown in nutrient broth and incubated 
on a shaker at 28 to $29^{\circ} \mathrm{C}$ for $24 \mathrm{~h}$ to produce cells in late log phase. The bacterial suspension was prepared by washing cells in $0.075 \mathrm{M}$ phosphate buffer and adjusting the concentration spectrophotometrically $(620 \mathrm{~nm})$. Bacterial concentration was confirmed by diluting and plating the suspension on NA plates, incubating for 3 days, and counting CFU.

Greenhouse tests. Seeds of Swingle citrumelo (Citrus paradisi Macfad. $\times$ Poncirus trifoliata (L). Raf.) were sown in $150-\mathrm{cm}^{3}$ containers (Stuewe \& Sons Inc., Corvallis, OR) containing Metro Mix 500 (The Scotts Co., Marysville, $\mathrm{OH}$ ), and seedlings were fertilized weekly with Peter's 20-10-20 Peat Lite Special (The Scotts Co.). Nine-month-old seedlings of each rootstock were then transplanted into $4,000-\mathrm{cm}^{3}$ containers and fertilized as before and supplemented with Osmocote (The Scotts Co.). Seedlings of uniform vigor and stem caliper (approximately 1 $\mathrm{cm}$ diameter) were cut back to allow a single dominant shoot to develop. When three to four leaves on the shoot reached three-fourths to full expansion, the entire plant was sprayed with test compounds using an airbrush at $20 \pm 5 \mathrm{ml}$ per plant. From 3 to 7 days after spray applications, three to four leaves per plant were injection infiltrated with inoculum on the abaxial surface of the leaf at three to four sites on each side of the midvein of the expanding leaves until the water-soaked area reached a total diameter of $6 \mathrm{~mm}$ per site. Inoculations were performed from 900 to $1200 \mathrm{~h}$ when stomata were fully open. Inoculated shoots were immediately enclosed in plastic bags for $48 \mathrm{~h}$. After removal of the bags, plants were rotated on the greenhouse bench twice weekly. After 14 days, lesions within each injectioninfiltration site were counted under a hand lens $(\times 10)$.

ISR and bacterial treatments in greenhouse tests. Greenhouse experiments were arranged in a completely randomized design with eight plants per spray treatment, three to four inoculated leaves per plant, and six to eight inoculation sites per leaf. Depending on the test, Actigard (acibenzolar- $S$-methyl, CGA-245704, 50 WP) at 20 or $40 \mathrm{mg}$ a.i./liter or Messenger (3\% a.i. harpin protein) at 20,40, or $60 \mathrm{mg}$ a.i./liter was sprayed on plants. Initial tests with $X$. axonopodis pv. citrumelo to determine efficacy and rates of ISRs were conducted from April to November 2000 in a greenhouse at the University of Florida, Citrus Research and Education Center in Lake Alfred. Tests to confirm efficacy of ISRs against $X$. axonopodis pv. citri were conducted from April to November 2001 and 2002 in a quarantine greenhouse at the Department of Agriculture and Consumer Services, Division of Plant Industry in Gainesville, FL. At both locations, day/night temperatures were $27 / 23 \pm 2{ }^{\circ} \mathrm{C}$.

Orchard trials. Based on the results of greenhouse activity against $X$. axonopodis pv. citri, Actigard and Messenger were evaluated in spray programs with and without copper oxychloride (COC, $\mathrm{Cu}$ pravit Verde, $50 \%$ metallic $\mathrm{Cu}$ ) and copper hydroxide $(\mathrm{CuOH}$, Kocide 2000, 35\% metallic $\mathrm{Cu}$ ), respectively, in replicated trials located in northern Paraná State, Brazil. Experimental design for orchard experiments was a randomized block with five blocks of three measurement trees per block (15 trees per treatment) for 10 treatments in 2000-2001 trials and eight treatments in 2001-2002 trials.

2000-2001 trials. One trial was conducted in the spring at Paranavaí with 4year-old IAPAR 73, a midseason orange variety (C. sinensis (L.) Osbeck), under low citrus canker disease incidence. A second trial was conducted in spring at Munhoz de Melo with 3-year-old Valencia, a late-season sweet orange, under moderate disease incidence. Tree spacing was $4.5 \times 6.5 \mathrm{~m}$ (approximately 350 to 400 trees per hectare), and the 10 treatments were arranged in a randomized block design with five blocks of five trees per treatment (five trees in a row, 25 trees per treatment). Sprays were applied on as many as six dates with a backpack sprayer calibrated to deliver approximately 2 liters of spray material per tree at incipient runoff from foliage. Treatments, spray timing, and dates of application are described in Table 1.

Foliar disease incidence (percentage of infected leaves) on the most recent mature foliage was assessed on eight limbs per tree (four limbs on each side of the tree) of the middle three trees in each five-tree block. In each orchard, two unsprayed checks were compared to evaluate the consistency of foliar disease evaluation and the uniformity of disease incidence in the plots. Readings of foliage were performed on 14 September, 14 November, 18 December, 17 January, 20 February, 16 March, 17 April, and 18 May. At Munhoz de Melo on each date, fruit on the ground under the middle three trees in each block was counted, and the presence or absence of canker on the fruit was recorded before removal. At harvest, 60 fruit per block (20 fruit from each quadrant of the middle three trees in each block) were picked to measure the incidence of citrus canker on fruit and quality of the juice (percentage of juice, acid, Brix) extracted from the fruit.

2001-2002 trials. Two trials were conducted in spring at Munhoz de Melo with two sweet orange varieties: site I was 4year-old Valencia orange with moderate disease incidence, and site II was 4-yearold Pera, a midseason orange with moderate disease incidence. Experimental design and disease evaluations were the same as in 2000-2001 trials. In each site, there were eight treatments as described in Table 1.

Foliar disease and fruit drop were evaluated for site I on 5 September, 3 October, 30 October, 29 November, 27 December, 28 January, 26 February, 27 March, and 25 April, and for site II on 19 September, 15 October, 8 November, 4 December, 2 January, 29 January, 26 February, 26 March, and 24 April.

Table 1. Spray treatments and schedules for orchard trials conducted in Paraná State, Brazil, in 2000-2001 and 2001-2002

\begin{tabular}{|c|c|c|c|}
\hline \multicolumn{2}{|c|}{ 2000-2001 at Paranavaí and Munhoz de Melo } & \multicolumn{2}{|c|}{ 2001-2002 at Munhoz de Melo sites I and II } \\
\hline Treatment & $\begin{array}{l}\text { Number and timing } \\
\text { of spray applications }\end{array}$ & Treatment & $\begin{array}{l}\text { Number and timing } \\
\text { of spray applications }\end{array}$ \\
\hline Unsprayed check-1; unsprayed check-2 & $\ldots$ & Unsprayed check-1; unsprayed check-2 & \\
\hline $\mathrm{COC}$ at $1.8 \mathrm{~g} /$ liter & All 6 times & $\mathrm{COC}$ at $1.8 \mathrm{~g} /$ liter & All 6 times \\
\hline $\mathrm{CuOH}$ at $1.3 \mathrm{~g} /$ liter & All 6 times & $\mathrm{CuOH}$ at $1.3 \mathrm{~g} /$ liter & All 6 times \\
\hline Actigard at $40 \mathrm{mg}$ a.i./liter $+\mathrm{COC}$ & All 6 times & Actigard at $20 \mathrm{mg}$ a.i./liter $+\mathrm{COC}$ and $\mathrm{COC}$ & 1,2 and $3,4,5,6$ \\
\hline Actigard + $\mathrm{COC}$ & $1,2,4$ & Actigard $+\mathrm{COC}$ and $\mathrm{COC}$ & $1,2,3$ and $4,5,6$ \\
\hline Actigard + $\mathrm{COC}$ and $\mathrm{COC}$ & $1,2,4$ and $3,5,6$ & Messenger at $62 \mathrm{mg}$ a.i./liter $+\mathrm{CuOH}$ and $\mathrm{CuOH}$ & 1,2 and $3,4,5,6$ \\
\hline Messenger at $62 \mathrm{mg}$ a.i./liter & All 6 times & Messenger $+\mathrm{CuOH}$ and $\mathrm{CuOH}$ & $1,2,3$ and $4,5,6$ \\
\hline Messenger $+\mathrm{CuOH}$ & All 6 times & Messenger $+\mathrm{CuOH}$ and $\mathrm{CuOH}$ & $1,3,5$ and 2,4 \\
\hline Messenger and $\mathrm{CuOH}$ & $1,3,5$ and 2,4 & & \\
\hline
\end{tabular}

y Spray timing and dates at Paranavaí were: (1) first flush, 15 September; (2) petal fall (PF), 19 October; (3) PF + 3 weeks, 14 November; (4) first summer flush (SF), 18 December; (5) SF + 4 weeks, 17 January; and (6) SF + 8 weeks, 17 February. Spray timing and dates at Munhoz de Melo were: (1) 22 September; (2) 19 October; (3) 14 November; (4) 18 December; (5) 16 January; and (6) 8 February.

${ }^{\mathrm{z}}$ Spray timing and date at site I were: (1) first flush, 6 September; (2) PF, 4 October; (3) PF + 2 weeks, 31 October; (4) SF, $30 \mathrm{November}$; (5) SF + 4 weeks, 3 January; and (6) SF +8 weeks, 30 January. Spray dates at site II were: (1) 17 September; (2) 16 October; (3) 9 November; (4) 5 December; (5) 4 January; and (6) 31 January. 
At harvest, fruit disease and fruit quality were evaluated on 60 fruit per block as in the 2000-2001 trials. Total fruit harvested from the middle three trees in each block was measured to calculate the yield and the percentage of total fruit that dropped due to citrus canker infection.

Statistical analysis. Greenhouse tests. Results of each greenhouse test were subjected to a factorial analysis of variance using SAS PROC GLM to test for effects of leaf, plant, and spray treatment on number of lesions per inoculation site. Since no interaction of leaf or plant on number of lesions per inoculation site was detected, a one-way ANOVA was performed on the number of lesions per site pooled across leaves and plants $(\mathrm{n}=21$ to 32$)$. Means were separated using Student-NewmanKeuls multiple range test at $P<0.05$.

Orchard trials. For each trial in each year, data for the area under the disease progress curve (AUDPC, calculated from seven or eight readings of foliar disease incidence), the incidence of fruit with canker, fruit drop, and juice quality parameters were subjected to a one-way ANOVA using SAS PROC GLM. Means $(n=5)$ were separated using Student-Newman-Keuls multiple range test at $P<0.05$.

\section{RESULTS}

Greenhouse tests. Discrete lesions were easily counted using a $\times 10$ hand lens at 14 days after stomatal inoculation of Swingle citrumelo leaves at $10^{3}$ or $10^{4} \mathrm{CFU} / \mathrm{ml}$. In two tests against $X$. axonopodis pv. citrumelo, a single application of Actigard at 40 $\mathrm{mg}$ a.i./liter reduced the number of CBS lesions by 55 to $80 \%$ (Table 2). Lesion reduction by Actigard at $40 \mathrm{mg} / \mathrm{liter}$ was similar at the two inoculum densities, but was less consistent at the $20-\mathrm{mg}$ rate, so the higher concentration was chosen for further evaluation against $X$. axonopodis pv. citri.

Control of $X$. axonopodis pv. citrumelo by Messenger at concentrations from 20 to $60 \mathrm{mg}$ a.i./liter was less consistent than control by Actigard (Table 2). In test 1, reduction of lesion number from 25 to $55 \%$ occurred at $40-$ and $60-\mathrm{mg}$ rates at $10^{3}$ or $10^{4} \mathrm{CFU} / \mathrm{ml}$. Messenger at all rates tested was ineffective in test 2 . The $40-\mathrm{mg}$ rate of Messenger was chosen for further evaluation of activity against citrus canker.

As found for $X$. axonopodis pv. citrumelo, ISR activity of Actigard against $X$. axonopodis pv. citri was more consistent than that obtained with Messenger (Table 3). Actigard reduced canker lesion development to the same level as it reduced $X$. axonopodis pv. citrumelo. Messenger reduced lesions in one of the two tests and only at the lower inoculum density in this case. Consistency of Actigard for control of canker was further confirmed in three replicate tests in 2002 (data not shown).

Orchard trials. 2000-2001. In each orchard, disease incidence was similar for
Table 2. Greenhouse evaluation of induced systemic resistance activity for different rates of Actigard and Messenger against Xanthomonas axonopodis pv. citrumelo injection-infiltrated at two inoculum concentrations into leaves of Swingle citrumelo ${ }^{\mathrm{x}}$

\begin{tabular}{lccccc}
\hline & \multicolumn{3}{c}{ Number of lesions per site } \\
\cline { 2 - 3 } Treatment & \multicolumn{1}{c}{$\mathbf{1 0}^{\mathbf{3}} \mathbf{C F U / m l}$} & & \multicolumn{1}{c}{$\mathbf{1 0} \mathbf{C F U} / \mathbf{m l}$} \\
\cline { 2 - 3 } \cline { 5 - 6 } Untreated check & $19.2 \mathrm{a}^{\mathrm{z}}$ & $12.8 \mathrm{a}$ & & $76.1 \mathrm{a}$ & $48.0 \mathrm{a}$ \\
Actigard 20 mg a.i./liter & $2.2 \mathrm{~b}$ & $12.2 \mathrm{a}$ & & $62.7 \mathrm{a}$ & $39.0 \mathrm{a}$ \\
Actigard 40 mg a.i./liter & $8.7 \mathrm{~b}$ & $3.8 \mathrm{~b}$ & & $39.1 \mathrm{~b}$ & $39.0 \mathrm{a}$ \\
Untreated check & $5.5 \mathrm{a}$ & $6.4 \mathrm{a}$ & & $42.9 \mathrm{a}$ & $44.2 \mathrm{a}$ \\
Messenger 20 mg a.i./liter & $4.3 \mathrm{ab}$ & $6.0 \mathrm{a}$ & & $32.8 \mathrm{ab}$ & $43.6 \mathrm{a}$ \\
Messenger 40 mg a.i./liter & $4.1 \mathrm{ab}$ & $5.9 \mathrm{a}$ & & $29.2 \mathrm{~b}$ & $38.5 \mathrm{a}$ \\
Messenger 60 mg a.i./liter & $2.2 \mathrm{~b}$ & $5.7 \mathrm{a}$ & & $19.6 \mathrm{~b}$ & $44.6 \mathrm{a}$ \\
\hline
\end{tabular}

${ }^{\mathrm{x}}$ Lesions counted 14 days after inoculation.

y Plants sprayed 3 (Actigard) or 7 (Messenger) days before inoculation.

${ }^{\mathrm{z}}$ For each compound, means $(\mathrm{n}=24$ to 32$)$ within columns followed by unlike letters indicate significant differences at the $P<0.05$ level according to Student-Newman-Keuls multiple range test.

Table 3. Greenhouse evaluation of induced systemic resistance activity for Messenger and Actigard against Xanthomonas axonopodis pv. citri injection-infiltrated at two inoculum concentrations into leaves of Swingle citrumelo ${ }^{\mathrm{x}}$

\begin{tabular}{lccccc}
\hline & \multicolumn{4}{c}{ Number of lesions per site } \\
\cline { 2 - 3 } \cline { 2 - 3 } \cline { 5 - 6 } Treatment & \multicolumn{2}{c}{$\mathbf{1 0}^{\mathbf{3}} \mathbf{C F U} / \mathbf{m l}$} & & \multicolumn{2}{c}{$\mathbf{1 0}^{\mathbf{4}} \mathbf{C F U} / \mathbf{m l}$} \\
\cline { 2 - 3 } \cline { 5 - 6 } Untreated check & $4.9 \mathrm{a}^{\mathbf{z}}$ & Test 2 & & Test $\mathbf{1}$ & Test 2 \\
Messenger & $3.3 \mathrm{~b}$ & $3.6 \mathrm{a}$ & & $37.4 \mathrm{~b}$ & $22.2 \mathrm{a}$ \\
Actigard & $3.0 \mathrm{~b}$ & $2.4 \mathrm{~b}$ & & $44.3 \mathrm{a}$ & $25.8 \mathrm{a}$ \\
\hline
\end{tabular}

${ }^{x}$ Lesions counted 14 days after inoculation.

y Plants sprayed with Actigard or Messenger at $40 \mathrm{mg}$ a.i./liter at 3 or 7 days, respectively, before inoculation in each test.

${ }^{\mathrm{z}}$ Means $(\mathrm{n}=24$ to 32$)$ within columns followed by unlike letters indicate significant differences at the $P<0.05$ level according to Student-Newman-Keuls multiple range test.

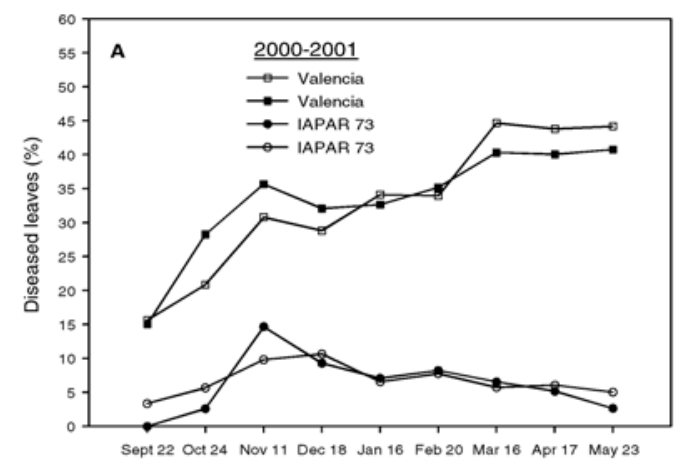

Evaluation date

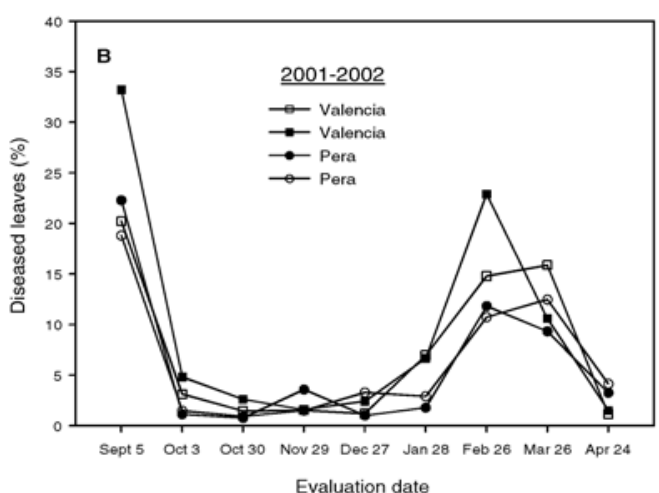

Fig. 1. Foliar disease incidence in unsprayed checks for: A, Valencia and IAPAR sweet orange orchards in Munhoz de Melo and Paranavaí, respectively, in 2000-2001 and B, Valencia and Pera sweet orange orchards in Munhoz de Melo in 2001-2002, Paraná State, Brazil. 
Table 4. Effects of foliar sprays of Actigard and Messenger with combinations of copper oxychloride and copper hydroxide for control of citrus canker on foliage and fruit in Paraná State, Brazil, 2000-2001, Valencia orange at Munhoz de Melo

\begin{tabular}{|c|c|c|c|c|}
\hline Treatment & $\mathbf{A U D P C}^{\mathbf{z}}$ & $\begin{array}{l}\text { Fruit with canker } \\
\qquad(\%)\end{array}$ & $\begin{array}{l}\text { Number of fruit dropped } \\
\text { per tree due to canker }\end{array}$ & $\begin{array}{l}\text { Fruit weight } \\
\text { (g/fruit) }\end{array}$ \\
\hline No spray check-1 & $32.2 \mathrm{a}$ & $69.0 \mathrm{a}$ & $21.5 \mathrm{abc}$ & $244 \mathrm{~b}$ \\
\hline No spray check-2 & $32.3 \mathrm{a}$ & $71.3 \mathrm{a}$ & $22.8 \mathrm{ab}$ & $251 \mathrm{~b}$ \\
\hline Copper hydroxide $(\mathrm{CuOH})(6 \times)$ & $19.8 \mathrm{~b}$ & $48.3 \mathrm{bc}$ & $13.3 \mathrm{abc}$ & $255 \mathrm{ab}$ \\
\hline Copper oxychloride (COC) $(6 \times)$ & $15.9 \mathrm{~b}$ & $35.0 \mathrm{c}$ & $5.5 \mathrm{bc}$ & $270 \mathrm{ab}$ \\
\hline Actigard + COC $(6 \times)$ & $18.4 \mathrm{~b}$ & $38.9 \mathrm{c}$ & $6.8 \mathrm{bc}$ & $292 \mathrm{a}$ \\
\hline Actigard $+\mathrm{COC}(3 \times)$ and $\mathrm{COC}(3 \times)$ & $16.3 \mathrm{~b}$ & $33.5 \mathrm{c}$ & $7.3 \mathrm{bc}$ & $266 \mathrm{ab}$ \\
\hline Actigard + COC $(3 \times)$ & $18.6 \mathrm{~b}$ & $51.2 \mathrm{bc}$ & $7.9 \mathrm{bc}$ & $268 \mathrm{ab}$ \\
\hline Messenger $+\mathrm{CuOH}(6 \times)$ & $13.3 \mathrm{~b}$ & $30.5 \mathrm{~b}$ & $5.3 \mathrm{c}$ & $265 \mathrm{ab}$ \\
\hline Messenger $(3 x)+\mathrm{CuOH}(2 \times)$ & $27.5 \mathrm{a}$ & $64.7 \mathrm{ab}$ & $15.9 \mathrm{abc}$ & $267 \mathrm{ab}$ \\
\hline Messenger $(6 \times)$ & $30.5 \mathrm{a}$ & $72.4 \mathrm{a}$ & $27.3 \mathrm{a}$ & $265 \mathrm{ab}$ \\
\hline
\end{tabular}

${ }^{\mathrm{z}}$ AUDPC $=$ area under the disease progress curve for foliage.

Table 5. Effects of foliar sprays of Actigard and Messenger with combinations of copper oxychloride and copper hydroxide for control of citrus canker on foliage and fruit in Paraná State, Brazil, 2000-2001, IAPAR 73 at Paranavaí

\begin{tabular}{|c|c|c|c|c|c|c|c|}
\hline Treatment & $\mathbf{A U D P C}^{\mathrm{x}}$ & $\begin{array}{l}\text { Fruit with } \\
\text { canker }(\%)\end{array}$ & $\begin{array}{l}\text { Fruit weight } \\
\text { (g/fruit) }\end{array}$ & $\begin{array}{c}\text { Juice content } \\
(\%)\end{array}$ & $\begin{array}{c}\text { Fruit acid } \\
(\%)\end{array}$ & $\begin{array}{c}\text { Fruit Brix } \\
\qquad(\%)\end{array}$ & Brix/acid \\
\hline No spray check-1 & $2.03 \mathrm{ab}^{\mathrm{y}}$ & $0.04 \mathrm{a}$ & $99 \mathrm{~b}$ & $53.7 \mathrm{a}$ & $0.85 \mathrm{~b}$ & $10.3 \mathrm{~b}$ & $12.10 \mathrm{a}$ \\
\hline No spray check-2 & $2.24 \mathrm{a}$ & $0.29 \mathrm{a}$ & $n t^{2}$ & nt & nt & nt & nt \\
\hline Copper hydroxide $(\mathrm{CuOH})(6 \times)$ & $0.69 \mathrm{bc}$ & $0.01 \mathrm{a}$ & $\mathrm{nt}$ & nt & nt & nt & nt \\
\hline Copper oxychloride (COC) $(6 \times)$ & $0.30 \mathrm{bc}$ & $0.01 \mathrm{a}$ & $105 \mathrm{~b}$ & $45.5 \mathrm{~b}$ & $0.91 \mathrm{~b}$ & $10.8 \mathrm{a}$ & $11.79 \mathrm{a}$ \\
\hline Actigard + COC $(6 x)$ & $0.46 \mathrm{bc}$ & $0.00 \mathrm{a}$ & $120 \mathrm{a}$ & $50.5 \mathrm{ab}$ & $0.85 \mathrm{~b}$ & $10.8 \mathrm{a}$ & $12.67 \mathrm{a}$ \\
\hline Actigard $+\operatorname{COC}(3 x)$ and $\operatorname{COC}(3 x)$ & $1.13 \mathrm{abc}$ & $0.02 \mathrm{a}$ & nt & nt & nt & nt & nt \\
\hline Actigard + $\operatorname{COC}(3 x)$ & $0.61 \mathrm{bc}$ & $0.02 \mathrm{a}$ & nt & nt & nt & nt & nt \\
\hline Messenger + $\mathrm{CuOH}(6 \times)$ & $0.28 \mathrm{bc}$ & $0.00 \mathrm{a}$ & $101 \mathrm{~b}$ & $47.3 \mathrm{~b}$ & $0.83 \mathrm{~b}$ & $10.5 \mathrm{ab}$ & $12.64 \mathrm{a}$ \\
\hline Messenger $(3 x)+\mathrm{CuOH}(2 x)$ & $0.51 \mathrm{bc}$ & $0.01 \mathrm{a}$ & nt & nt & nt & nt & nt \\
\hline Messenger $(6 x)$ & $0.17 \mathrm{c}$ & $0.00 \mathrm{a}$ & $129 \mathrm{a}$ & $46.1 \mathrm{~b}$ & $1.24 \mathrm{a}$ & $9.4 \mathrm{c}$ & $7.56 \mathrm{~b}$ \\
\hline
\end{tabular}

${ }^{\mathrm{x}}$ AUDPC $=$ area under the disease progress curve for foliage.

${ }^{y}$ Means $(\mathrm{n}=5)$ within columns followed by unlike letters indicate significant differences at the $P<0.05$ according to Student-Newman-Keuls multiple range test.

${ }^{\mathrm{z}} \mathrm{nt}=$ not tested.

the two unsprayed checks confirming the reproducibility of foliar disease evaluation and uniformity of disease pressure in the plots (Fig. 1A). At the Munhoz de Melo site, canker incidence increased through the season on untreated Valencia orange trees exposed in the spring to moderate disease pressure (Fig. 1A). Area under the disease progress curve (AUDPC) was reduced by all treatments that included COC and $\mathrm{CuOH}$ except the treatment of three Messenger plus two $\mathrm{CuOH}$ sprays (Table 4). This $\mathrm{Cu}$ program included one spray in the midspring (spray no. 2) and one in summer (spray no. 4) compared with other treatments that received three sprays early in the season or six sprays throughout the season of $\mathrm{Cu}$ formulations alone or in combination with Actigard or Messenger. The combination of Actigard or Messenger with $\mathrm{Cu}$ formulations did not reduce AUDPC compared with treatments with $\mathrm{Cu}$ alone. Six sprays of Messenger without $\mathrm{CuOH}$ were ineffective for control of foliar disease. The same relationship among treatments was observed for reduction of canker incidence on fruit and prevention of fruit drop due to canker infection (Table 4). As was the case for foliar disease, combination of ISRs with $\mathrm{Cu}$ formulations did not reduce fruit disease incidence and premature drop compared with treatments with $\mathrm{Cu}$ alone (Table 4). The treatments with Messenger alone and Messenger + two $\mathrm{CuOH}$ sprays were the least effective for reducing canker incidence on fruit and prevention of fruit drop. Except for fruit weight, treatments did not affect fruit quality parameters (percent juice, Brix, acid, Brix/acid; data not shown) for the lateseason Valencia fruit compared with the untreated checks (data not shown).

At the Paranavaí site, initial disease incidence was low, and canker developed early and then declined thereafter (Fig. 1A). All spray treatments, except the three Actigard + COC plus three COC sprays program, significantly reduced AUDPC compared with untreated check-2 but not untreated check-1 (Table 5). Lack of statistical separation among treatments was due to low foliar disease at this site. Canker incidence was even less on fruit than on foliage, and fruit drop was not measurable. The relationship of treatments to reduction of incidence of canker on fruit was similar to that for foliage, but no significant differences in fruit disease were observed among treatments (Table 5). Canker was not detected on fruit for treatments with full season application ISRs: six sprays of Actigard + COC or six sprays of Messenger. These treatments also increased fruit weight but reduced percent juice of the midseason variety, IAPAR 73. Six sprays of Messenger delayed color-break (fruit remained green) and increased acid, reduced Brix and Brix/acid ratio of the juice.
2001-2002. In each orchard, disease incidence was similar for the two unsprayed checks, again confirming the reproducibility of foliar disease evaluation and uniformity of disease pressure in the plots (Fig. 1B). At Munhoz de Melo site I, Valencia orange trees in the same orchard as in the 2000-2001 trial had moderate canker disease early in the spring. Without treatment, disease increased, but after the rains stopped for several weeks in January and February, disease incidence declined to a low level and did not increase until the end of the season when rains resumed (Fig. 1B). In 2001-2002, ISRs were combined with the same $\mathrm{Cu}$ formulations as in 2000 2001 and ISR treatments made at the first through third spray timings. All treatments reduced AUDPC, incidence of fruit infection, and fruit drop due to canker compared with the untreated check treatments (Table 6). Treatments with combinations of two or three applications of Actigard or Messenger were no more effective than $\mathrm{Cu}$ formulations alone. No treatments significantly increased fruit yield, although as a group, treated trees had higher fruit numbers than unsprayed checks. None of the treatments affected the quality of lateseason Valencia fruit at harvest (data not shown).

At Munhoz de Melo site II, Pera orange trees were exposed to slightly lower canker disease incidence than in site I, but the 
Table 6. Effects of foliar sprays of Actigard and Messenger with formulations of copper oxychloride and copper hydroxide for control of citrus canker on foliage and fruit and fruit drop of Valencia orange (site I) and Pera orange (site II) in Munhoz de Melo, Paraná, Brazil, in 2001-2002

\begin{tabular}{|c|c|c|c|c|c|c|c|c|c|c|c|c|}
\hline \multirow[b]{2}{*}{ Site } & \multicolumn{2}{|c|}{ AUDPCy } & \multicolumn{2}{|c|}{$\begin{array}{c}\text { Fruit w/canker } \\
(\%)\end{array}$} & \multicolumn{2}{|c|}{$\begin{array}{l}\text { Fruit dropped due to } \\
\text { canker infection (\%) }\end{array}$} & \multicolumn{2}{|c|}{$\begin{array}{l}\text { Fruit dropped due } \\
\text { to other causes }(\%)\end{array}$} & \multicolumn{2}{|c|}{$\begin{array}{c}\text { Total fruit } \\
\text { dropped }(\%)\end{array}$} & \multicolumn{2}{|c|}{$\begin{array}{c}\text { Total fruit } \\
\text { per tree }\end{array}$} \\
\hline & I & II & I & II & I & II & I & II & I & II & I & II \\
\hline No spray check-1 & $6.84 \mathrm{a}^{\mathrm{z}}$ & $5.75 \mathrm{a}$ & $17.88 \mathrm{a}$ & $7.66 \mathrm{a}$ & $3.67 \mathrm{a}$ & $3.42 \mathrm{a}$ & $6.47 \mathrm{a}$ & $1.59 \mathrm{a}$ & $10.13 \mathrm{a}$ & $5.00 \mathrm{a}$ & $373 \mathrm{a}$ & $468 \mathrm{a}$ \\
\hline No spray check-2 & $8.28 \mathrm{a}$ & $5.32 \mathrm{a}$ & $13.56 \mathrm{a}$ & $6.04 \mathrm{a}$ & $2.75 \mathrm{a}$ & $2.91 \mathrm{a}$ & $8.43 \mathrm{a}$ & $1.59 \mathrm{a}$ & $11.17 \mathrm{a}$ & $4.50 \mathrm{a}$ & $324 \mathrm{a}$ & $457 \mathrm{a}$ \\
\hline $\begin{array}{l}\text { Copper hydroxide } \\
(\mathrm{CuOH})(6 \times)\end{array}$ & $2.06 \mathrm{~b}$ & $3.31 \mathrm{~b}$ & $0.33 \mathrm{~b}$ & $3.67 \mathrm{a}$ & $0.53 \mathrm{~b}$ & $0.97 \mathrm{~b}$ & $5.99 \mathrm{a}$ & $1.90 \mathrm{a}$ & $6.53 \mathrm{a}$ & $2.87 \mathrm{ab}$ & $432 \mathrm{a}$ & $519 \mathrm{a}$ \\
\hline $\begin{array}{l}\text { Copper oxychloride } \\
\text { (COC) }(6 \times)\end{array}$ & $2.28 \mathrm{~b}$ & $2.70 \mathrm{~b}$ & $0.00 \mathrm{~b}$ & $2.35 \mathrm{a}$ & $0.55 \mathrm{~b}$ & $0.72 \mathrm{~b}$ & $6.37 \mathrm{a}$ & $1.65 \mathrm{a}$ & $6.94 \mathrm{a}$ & $2.37 \mathrm{~b}$ & $446 \mathrm{a}$ & $418 \mathrm{a}$ \\
\hline COC + Actigard $(2 x)$ & $2.12 \mathrm{~b}$ & $2.39 \mathrm{~b}$ & $1.95 \mathrm{~b}$ & $1.68 \mathrm{a}$ & $0.65 \mathrm{~b}$ & $0.92 \mathrm{~b}$ & $7.27 \mathrm{a}$ & $2.22 \mathrm{a}$ & $7.92 \mathrm{~b}$ & $2.33 \mathrm{~b}$ & $418 \mathrm{a}$ & $460 \mathrm{a}$ \\
\hline COC + Actigard $(3 x)$ & $2.25 \mathrm{~b}$ & $2.25 \mathrm{~b}$ & $2.99 \mathrm{~b}$ & $1.99 \mathrm{a}$ & $0.72 \mathrm{~b}$ & $0.83 \mathrm{~b}$ & $7.24 \mathrm{a}$ & $1.41 \mathrm{a}$ & $7.96 \mathrm{ab}$ & $3.05 \mathrm{ab}$ & 389 a & $408 \mathrm{a}$ \\
\hline $\mathrm{CuOH}+$ Messenger $(2 \times)$ & $2.29 \mathrm{~b}$ & $2.07 \mathrm{~b}$ & $1.33 \mathrm{~b}$ & $5.21 \mathrm{a}$ & $0.67 \mathrm{~b}$ & $0.82 \mathrm{~b}$ & $6.55 \mathrm{a}$ & $1.89 \mathrm{a}$ & $7.22 \mathrm{ab}$ & $2.70 \mathrm{ab}$ & $467 \mathrm{a}$ & $458 \mathrm{a}$ \\
\hline $\mathrm{CuOH}+$ Messenger $(3 x)$ & $2.00 \mathrm{~b}$ & $1.96 \mathrm{~b}$ & $4.33 \mathrm{~b}$ & $3.68 \mathrm{a}$ & $1.15 \mathrm{~b}$ & $0.88 \mathrm{~b}$ & $9.52 \mathrm{a}$ & $2.21 \mathrm{a}$ & $10.67 \mathrm{a}$ & $3.05 \mathrm{ab}$ & $380 \mathrm{a}$ & $442 \mathrm{a}$ \\
\hline
\end{tabular}

y AUDPC $=$ area under the disease progress curve for foliage.

${ }^{\mathrm{z}}$ Means $(\mathrm{n}=5)$ within columns followed by unlike letters indicate significant differences at $P<0.05$ according to Student-Newman-Keuls multiple range test.

pattern of disease progress was similar (Fig. 1B). All treatments reduced AUDPC and canker-caused fruit drop compared with the untreated check treatments (Table 6). Incidence of fruit infection was numerically lower on treated trees, but the low incidence and high variability did not allow statistical separation of the treatments from the untreated checks. Treatments with combinations of two or three applications of Actigard or Messenger were no more effective than $\mathrm{Cu}$ formulations alone. None of the treatments affected fruit yield or quality at harvest (data not shown).

\section{DISCUSSION}

In the greenhouse assays, reduction of lesions by Actigard (acibenzolar- $S$-methyl) and Messenger (harpin protein) was presumed to be due to ISR and not to direct antimicrobial activity of the compounds. Although induction of plant antimicrobial compounds was not assayed in the present study, ISR activity was likely because: (i) the compounds were applied well in advance to induce systemic activity prior to inoculation, and (ii) bacteria were infiltrated through stomata to minimize direct contact with the compounds on the leaf surface. Bacterial infiltration into the leaf mesophyll produced discrete lesions at the point of stomatal infection which permitted quantitative assessment of ISR activity against $X$. axonopodis pv. citrumelo and $X$. axonopodis pv. citri. ISR compounds at 20 to $40 \mathrm{mg}$ a.i./liter controlled citrus bacterial spot and canker in greenhouse assays, but the activity of Actigard appeared to be more consistent than that of Messenger. Actigard reduced lesions at concentrations effective for field control of Xanthomonas spot of bell pepper (24).

Based on greenhouse activity against citrus bacterial diseases, Actigard and Messenger were applied with $\mathrm{Cu}$ in an attempt to reduce bacterial multiplication in the leaf and complement contact activity early in the season. In four orchard trials, ISRs with or without $\mathrm{Cu}$ formulations did not reduce citrus canker incidence on foliage or fruit or reduce fruit drop in susceptible sweet oranges compared with $\mathrm{Cu}$ alone. As previously demonstrated in Brazil and Argentina $(7,15,16,20), \mathrm{Cu}$ alone was moderately to highly effective for reducing foliar disease, fruit infection, and premature fruit drop on susceptible sweet orange varieties depending on the disease pressure.

A potential side effect of ISRs on fruit was detected for the midseason orange, IAPAR 73, but not for late-season Valencia orange. ISRs increased fruit weight, a desirable characteristic for IAPAR 73, which produces undersized fruit for the fresh market. However, Messenger also retarded fruit maturation and delayed color-break (fruit remained green), which could delay harvest of this variety.

Foliage and fruit disease control was best achieved with six sprays of either $\mathrm{Cu}$ formulation, but programs that reduced or delayed $\mathrm{Cu}$ sprays were less effective. This finding confirms that $\mathrm{Cu}$ coverage is critical during the early stages of foliage and fruit development because immature tissues are most susceptible $(26,28)$. It is also well established from research in South America $(16,28)$ and Japan (14) that control of early infection of fruit greatly reduces premature fruit drop. In the 20012002 trials, fruit drop was reduced from $3.2 \%$ (unsprayed) to 0.62 and $0.85 \%$ (treatments with $\mathrm{Cu}$ applied full season) for Valencia and Pera orange, respectively. For sweet oranges that are principally used for juice processing, prevention of fruit drop is much more important than reduction of fruit blemishes.

\section{ACKNOWLEDGMENTS}

We thank L. C. Teixeira and the support staff at the Instituto Agronômico do Paraná for their assistance in conducting orchard trials in Brazil. We also recognize the technical support of D. L. Drouillard and D. B. Bright at the Citrus Research and Education Center, Lake Alfred, FL, and X. Sun and M. Nielsen at the quarantine facilities at Florida Department of Agriculture and Consumer Services, Division of Plant Industry in Gainesville.

\section{LITERATURE CITED}

1. Alva, A. K., Graham, J. H., and Anderson, C. A. 1995. Soil pH and copper effects on young 'Hamlin' orange trees. Soil Sci. Soc. Am. J. 59:481-487.

2. de Capdeville, G., Beer, S. V., Wilson, C. L., and Aist, J. R. 2001. Blue mold decay of apples reduced by post-harvest treament with harpin. Phytopathology 91:S193.

3. Gorlach, J., Volrath, S., Knauf-Beiter, G. Hengy, G., Beckhove, U., Kogel, K.-H., Oostendorp, M., Staub, T., Ward, E., Kessmann, H., and Ryals, J. 1996. Benzathiadiazole, a novel class of inducers of systemic acquired resistance, activates gene expression and disease resistance in wheat. Plant Cell 8:629-643.

4. Gottwald, T. R., and Graham, J. H. 1992. A device for precise and nondisruptive stomatal inoculation of leaf tissue with bacterial pathogens. Phytopathology 82:930-935.

5. Gottwald, T. R., and Timmer, L. W. 1995. The efficacy of windbreaks in reducing the spread of citrus canker caused by Xanthomonas campestris pv. citri. Trop. Agric. 72:194-201.

6. Gottwald, T. R., Sun, X., Riley, T., Graham, J. H., Ferrandino, F., and Taylor, E. L. 2002. Geo-referenced spatiotemporal analysis of the urban citrus canker epidemic in Florida. Phytopathology 92:361-377.

7. Graham, J. H. 1998. Citrus canker: Control efforts in Brazil, prognosis for Florida. Citrus Ind. 79(8):54-57.

8. Graham, J. H. 2001. Varietal susceptibility to citrus canker: Observations from southern Brazil. Citrus Ind. 82(6):15-17.

9. Graham, J. H., and Gottwald, T. R. 1991 Research perspectives on eradication of citrus bacterial diseases in Florida. Plant Dis. 75:1193-1200.

10. Graham, J. H., Gottwald, T. R., Riley, T. D., and Achor, D. 1992. Penetration through leaf stomata and growth of strains of Xanthomonas campestris in citrus cultivars varying in susceptibility to bacterial diseases. Phytopathology 82:1319-1325.

11. Graham, J. H., Gottwald, T. R., Riley, T. D., and Bruce, M. A. 1992. Susceptibility of citrus fruit to bacterial spot and citrus canker. Phytopathology 82:452-457.

12. Kessmann, H., Stauv, T., Hoffmann, C., Maetzke, T., and Herzog, J. 1994. Induction of systemic acquired disease resistance in plants by chemicals. Annu. Rev. Phytopathol. 32:439459.

13. Kloepper, J. W., Tuzun, S., and Kuc, J. A 1992. Proposed definitions related to induced resistance. Biocontrol Sci. Technol. 2:349-351.

14. Kuhara, S. 1978. Present epidemic status and control of the citrus canker disease (Xanthomonas citri (Hasse) Dowson) in Japan. Rev. 
Plant Prot. Res. 11:132-142.

15. Leite, R. P., Jr. 1990. Cancro cítrico - prevenção e controle no Paraná. IAPAR, Londrina, PR, Brazil. Circ. no. 61.

16. Leite, R. P., Jr., and Mohan, S. K. 1990. Integrated management of the citrus bacterial canker disease caused by Xanthomonas campestris pv. citri in the State of Paraná, Brazil. Crop Prot. 9:3-7.

17. Leite, R. P., Jr., Mohan, S. K., Pereira, A. L. G., and Campacci, C. A. 1987. Controle integrado de cancro cítrico - efeito da resistência genética e da aplicação de bactericidas. Fitopatol. Brás. 12:257-263.

18. Marco, G. M., and Stall, R. E. 1983. Control of bacterial spot of pepper initiated by strains of Xanthomonas campestris pv. vesicatoria that differ in sensitivity to copper. Plant Dis. 67:779-781.

19. McGuire, R. G. 1988. Evaluation of bactericidal chemicals for control of Xanthomonas on citrus. Plant Dis. 72:1016-1020.

20. Muraro, R. P., Roka, F. M., and Spreen, T. H. 2002. Grower costs of having citrus canker in Florida with an overview of Argentina's citrus canker control program. Staff Pap. SP02-3. Dept. Food and Resource Economics, University of Florida, IFAS, Gainesville.
21. Namekata, T., and Lasca, C. C. 1967. Obtenção de bacteria, Xanthomonas citri (Hasse) Dowson, resistente ao sulfato de estreptomycina. Rev. Soc. Bras. Fitopatol. 1(1):9.

22. Rinaldi, D. A. M. F., and Leite, R. P., Jr. 2000. Adaptation of Xanthomonas axonopodis pv. citri population to the presence of copper compounds in nature. Proc. Int. Soc. Citric. 2:1064.

23. Ritchie, D. F., and Dittspongpitch, V. 1991. Copper- and streptomycin-resistant strains and host differentiated races of Xanthomonas campestris pv. vesicatoria in North Carolina. Plant Dis. 75:733-736.

24. Romero, A. M., Kousik, C. S., and Ritchie, D. F. 2001. Resistance to bacterial spot in bell pepper induced by acibenzolar- $S$-methyl. Plant Dis. 85:189-194.

25. Schubert, T. S., Rizvi, S. A., Sun, X., Gottwald, T. R., Graham, J. H., and Dixon, W. N. 2001. Meeting the challenge of eradicating citrus canker in Florida - again. Plant Dis. 85:340-356.

26. Stall, R. E., Marcó, G. M., and Canteros de Echenique, B. I. 1982. Importance of mesophyll in mature-leaf resistance to cancrosis of citrus. Phytopathology 72:1097-1100.

27. Stall, R. E., Miller, J. W., Marco, G. M., and
Canteros de Echenique, B. I. 1980. Population dynamics of Xanthomonas citri causing cancrosis of citrus in Argentina. Proc. Fla. State Hortic. Soc. 93:10-14.

28. Stall, R. E., Miller, J. W., Marco, G. M., and Canteros de Echenique, B. I. 1982. Timing of sprays to control cancrosis of grapefruit in Argentina. Proc. Int. Soc. Citric. 1:414-417.

29. Stall, R. E., and Thayer, P. L. 1962. Streptomycin resistance of the bacterial spot pathogen and control with streptomycin. Plant Dis. Rep. 46:389-392.

30. Tally, A., Oostendorp, M., Lawtion, K., Staub, T., and Bassi, B. 1999. Commercial development of elicitors of induced resistance to pathogens. Pages 357-370 in: Induced Plant Defenses Against Pathogens and Herbivores. Biochemistry, Ecology, and Agriculture. A. A. Agrawal, S. Tuzun, and E. Bent, eds. American Phytopathological Society, St. Paul, MN.

31. Timmer, L. W. 1988. Evaluation of bactericides for control of citrus canker in Argentina Proc. Fla. State Hortic. Soc. 101:6-9.

32. Wei, Z. M., Laby, R. J., Zumoff, C. H., Bauer, D. W., He, S. Y., Collmer, A., and Beer, S. V. 1992. Harpin, elictor of the hypersensitive response produced by the plant pathogen $\mathrm{Er}$ winia amylovora. Science 257:85-88. 